\title{
MODEL PEMBELAJARAN KONTEKSTUAL IPA MELALUI PENDEKATAN OUTDOOR LEARNING DI SDN SUMURJALAK 2 PLUMPANG TUBAN
}

\author{
${ }^{1)}$ Midya Yuli Amreta, Institut Agama Islam Sunan Giri Bojonegoro, \\ email:midya@sunan-giri.ac.id \\ ${ }^{2)}$ Ahmad Farid Utsman, Institut Agama Islam Sunan Giri Bojonegoro, \\ email: utsman@sunan-giri.ac.id
}

\begin{abstract}
Learning contextual on IPA is learning of nature science who insists on the links between matter learning of surely clear. This study attempts to described and analyze learning model contextual IPA in SDN sumurjalak 2 plumpang, described and analyze outdoor learning in SDN sumurjalak 2 plumpang, and described and analyze learning model contextual IPA through outdoor learning in SDN sumurjalak 2 plumpang. This study adopted qualitative approaches that uses the design cases. The data collection was done through technique interview, observation, and documentation. Technique data analysis covering reduction data, presentation of data, and the withdrawal of conclusion. Informants in this research among others Headmaster, teachers, and school tuition. The results of research has done shown that: (1) learning science using contextual learning model it can enhance understanding drafts participants students. In learning use contextual teachers capable of mengondisikan students by stressing towards the process of full involvement students to own mengkostruksikan matter learned and connecting with the real life causing students to can use them in their lives.( 2 ) outdoor approach learning is an alternative to science suitable learning adventure and observation directly in the real environment around with link science, environment, and the technology.( 3 ) contextual learning model in learning science capable of learning constructive provides science and give meaningful study results for learners.Students can find arrange their own that they can be meaningful and unforgetable. Students get easier to understand the content of learning, they also have higher critical thinking and creative on question and answer session in learning science.
\end{abstract}

Keywords : Contextual Learning, Science, Outdoor Learning

\section{Pendahuluan}

Jenjang sekolah dasar merupakan pondasi dasar dari semua jenjang sekolah selanjutnya. Diungkapkan Suprijono, bahwa tujuan penyelenggaraan pendidikan dasar adalah menyiapkan peserta didik agar menjadi manusia yang bermoral, menjadi warga negara yang mampu melaksanakan kewajiban-kewajibannya, dan menjadi orang dewasa yang mampu memperoleh pekerjaan. ${ }^{1}$ Secara operasional, tujuan pokok pendidikan dasar adalah membantu peserta didik dalam mengembangkan kemampuan intelektual dan mentalnya, proses perkembangan sebagai individu yang mandiri, proses perkembangan sebagai makhluk sosial, belajar hidup

\footnotetext{
${ }^{1}$ Suprijono, Agus. 2009. Cooperative Learning Teori dan Aplikasi Paikem. Yogyakarta: Pustaka Belajar.
} 
menyesuaikan diri dengan berbagai perubahan, dan meningkatkan kreativitas. Teori yang dikemukakan oleh Piaget bahwa anak SD pada umumnya berusia 6-12 tahun berada pada tahap operasional konkrit karena berfikir logikanya peserta didik SD berdasarkan manipulasi obyek konkrit atau pengalaman yang langsung dialaminya. Sesuai dengan teori Piaget tersebut, maka peserta didik perlu belajar dari apa yang dilihat, didengar dan dirasakan sehari-hari. Lingkungan disekitar peserta didik menjadi salah satu sumber belajar peserta didik. Kurang adanya pengkaitan materi dengan keadaan sehari-hari menjadikan peserta didik kurang paham dalam menerima materi, karena peserta didik hanya menerima teori saja, tanpa mengetahui manfaat dari pembelajaran tersebut. Begitu pula dengan pembelajaran yang masih bersifat konvensional akan menjadikan peserta didik tidak semangat dalam belajar, kurangnya guru dalam dalam melibatkan peserta didik menjadikan pembelajaran hanya berpusat pada pada guru dan membuat pembelajaran menjadi membosankan. Selain itu tidak adanya kegiatan yang mampu menumbuhkan kreativitas peserta didik, sehingga peserta didik belum mendapatkan hasil belajar yang maksimal.

Ilmu Pengetahuan Alam (IPA) berkaitan dengan cara mencari tahu tentang alam secara sistematis, penguasaan kumpulan pengetahuan yang berupa kumpulan fakta, konsep, prinsip dan juga merupakan suatu proses penemuan sehingga sangat penting untuk dipelajari. ${ }^{2}$ Pembelajaran IPA sebaiknya dilaksanakan secara ilmiah untuk menumbuhkan kemampuan berfikir, bekerja dan bersikap ilmiah serta mengkomunikasikan sebagai aspek penting kecakapan hidup. ${ }^{3}$ Namun hasil observasi yang dilakukan oleh peneliti pada pembelajaran IPA, pembelajaran masih menekankan pada sejumlah fakta dan konsep. Guru juga masih sering menggunakan metode ceramah, meskipun kadang diselingi dengan metode tanya jawab, namun guru belum mampu mengkondisikan peserta didik untuk fokus pada materi. Masih banyak peserta didik yang bercengkrama dengan teman sebangkunya, ada yang memukul-mukul meja bahkan ada yang mengantuk.

Penggabungan antara model pembelajaran kontekstual IPA dengan pendekatan Outdoor Learning merupakan satu jalan bagaimana guru dapat meningkatkan kapasitas belajar peserta didik. Karena model pembelajaran kontekstual membangun keterkaitan, independensi, relasi-

\footnotetext{
${ }^{2}$ Nurhaningtyas Agustin, \& Munthofi'ah. (2019). PENERAPAN MODEL BELAJAR INKUIRI UNTUK MENINGKATKAN PRESTASI BELAJAR IPA DALAM MATERI POKOK DAUR HIDUP PADA SISWA KELAS V MI SUNAN KALIJOGO. PREMIERE : Journal of Islamic Elementary Education, 1(1), 87-102. ${ }^{3}$ Widi Wisudawati, Asih dan Eka Sulistyowati. 2014. Metodologi Pembelajaran IPA, Jakarta: Bumi Aksara.
} 
relasi penuh makna antara apa yang dipelajari dengan realitas, lingkungan personal, sosial dan kultural yang terjadi sekarang ini. ${ }^{4}$ Pembelajaran kontekstual merupakan konsep belajar yang membantu guru mengaitkan antara pengetahuan yang dimilikinya dengan penerapannya dalam kehidupan mereka sebagai anggauta keluarga dan masyarakat. ${ }^{5}$ Dengan demikian kualitas pembelajaran IPA di sekolah diharapkan dapat memberi hasil yang optimal bagi prestasi belajar peserta didik.

\section{Pembelajaran Kontekstual}

Model pembelajaran kontektual adalah suatu model pembelajaran yang menekankan kepada proses keterlibatan peserta didik secara penuh untuk dapat mengkostruksikan sendiri materi yang dipelajari dan menghubungkan dengan situasi kehidupan nyata sehingga mendorong peserta didik untuk dapat menerapkannya dalam kehidupan mereka. Hakikat pembelajaran kontekstual adalah sebuah sistem yang mendorong peserta didik untuk membangun keterkaitan, independensi, relasi-relasi penuh makna antara apa yang dipelajari dengan realitas, lingkungan personal, sosial dan kultural yang terjadi sekarang ini. ${ }^{6}$ Pembelajaran kontekstual atau Contextual Teacing and Learning (CTL) adalah sebuah sistem yang bersifat menyeluruh yang menyerupai cara bekerja alam. Pembelajaran kontekstual merupakan konsep belajar yang membantu guru mengaitkan antara pengetahuan yang dimilikinya dengan penerapannya dalam kehidupan mereka sebagai anggauta keluarga dan masyarakat. ${ }^{7}$

Pembelajaran kontekstual medorong peserta didik membuat hubungan antara pengetahuan yang dimilikinya dan penerapannya dalam kehidupan mereka sendiri-sendiri, hal ini seperti yang disampaikan Trianto, bahwa suatu konsepsi yang membantu guru mengaitkan konten mata pelajaran dengan situasi dunia nyata. ${ }^{8}$ Dengan demikian pembelajaran kontekstual akan menghasilkan dasar-dasar pengetahuan yang mendalam dimana peserta didik kaya akan pemahaman masalah dan cara untuk menyelesaikannya. Peserta didik mampu menggunakan pengetahuannya untuk menyelesaikan masalah-masalah baru dan belum pernah dihadapi, serta memiliki tanggung jawab terhadap belajarnya seiring dengan peningkatan pengalaman dan pengetahuan mereka.

\footnotetext{
${ }^{4}$ Sanjaya, Wina. 2008. Strategi Pembelajaran Berorientasi Standar Proses Pendidikan. Jakarta: Kencana.

${ }^{5}$ Suryanti, dkk. 2008. Model-Model Pembelajaran Inovatif. Surabaya: Unesa University Press

${ }^{6} \operatorname{Ibid}(3)$

${ }^{7} \operatorname{Ibid}(4)$

${ }^{8}$ Trianto. 2009. Mendesain Model Pembelajaran Inovatif-Progresif, Jakarta: Kencana.
} 


\section{Ilmu Pengetahuan Alam (IPA)}

Ilmu Pengetahuan Alam (IPA) berkaitan dengan cara mencari tahu tentang alam secara sistematis, penguasaan kumpulan pengetahuan yang berupa kumpulan fakta, konsep, prinsip dan juga merupakan suatu proses penemuan sehingga sangat penting untuk dipelajari. ${ }^{9}$ Secara harfiah Ilmu pengetahuan Alam (IPA) disebut sebagai ilmu yang mempelajari peristiwa-peristiwa yang terjadi di alam. Ilmu pengetahuan Alam (IPA) mempelajari gejalagejala alam yang perkembangannya tidak hanya ditandai oleh adanya kumpulan fakta, tetpi oleh metode ilmiah beserta sikap ilmiah. Ilmu pengetahuan Alam (IPA) berupaya selalu membangkitkan untuk meningkatkan pemahaman peserta didik tentang gejala-gejala alam beserta isinya yang terjadi di dalamnya.

\section{Outdoor Learning}

Kegiatan pembelajaran Outdoor Learning merupakan kegiatan pembelajaran yang dilakukan peserta di luar kelas. Kegiatan Outdoor Learning dilakukan bisa dilakukan dimana saja dan tempat tersebut bisa digunakan oleh peserta didik sebagai sumber belajar secara langsung dan nyata. Menurut Husamah Outdoor Learning merupakan aktivitas luar sekolah yang berisi kegiatan di luar kelas atau sekolah dan di alam bebas lainnya, seperti: bermain di lingkungan sekolah, taman, perkampungan pertanian/nelayan, berkemah, dan kegiatan yang bersifat kepetualangan, serta pengembangan aspek pengetahuan yang relevan.

Outdoor Learning mengaktifkan peserta didik untuk mengeksplorasi dan menciptakan pemahaman materi pembelajaran; mengembangkan pengetahuan; aktif; kreatif dan imajinatif; mempraktikkan keterampilan baru; belajar tentang risiko; merangsang indera mereka dan membangun hubungan dan persahabatan. Hal ini sejalan dengan pendapat Husamah bahwa peserta didik dapat memahami dan menghayati aspek-aspek kehidupan yang ada di lingkungannya, sehingga dapat membentuk pribadi yang tidak asing dengan kehidupan membentuk sekitarnya, serta dapat memupuk cinta lingkungan. Proses pembelajaran secara langsung membuat peserta didik mempunyai pengalaman yang nyata dan konkret sehingga membuat peserta didik mumah memahami materi dan terhindar dari kesalahan persepsi.

\footnotetext{
${ }^{9}$ Ibid (2)
} 


\section{Metodologi}

Metode Penelitian ini menggunakan pendekatan kualitatif, dengan maksud peneliti dapat mendeskripsikan secara terperinci dan jelas, serta mendapat data yang mendalam dari fokus penelitian yaitu tentang metode pembelajaran kontekstual IPA melalui Outdoor Learning SDN Sumurjalak 2 Plumpang Tuban. Jenis penelitian ini menggunakan jenis studi kasus.

Dalam penelitian ini, peneliti bermaksud ingin mengetahui tentang model pembelajaran kontekstual IPA melalui Outdoor Learning di SDN Sumurjalak 2 Plumpang Tuban. Dengan demikian, peneliti akan memaparkan realitas metode pembelajaran kontekstual IPA melalui Outdoor Learning di SDN Sumurjalk 2 Plumpang Tuban, yaitu dengan mendeskripsikan fenomena-fenomena yang terjadi. Selain itu juga, peneliti mengamati secara langsung terhadap fenomena tersebut yang tampak, mengambil informasi melalui responden-responden mengenai situasi dan kondisi dari objek penelitia, dan dokumen-dokumen pendukung lainnya.

Sumber data primer dari peneltitian ini adalah Kepala sekolah, guru, dan peserta didik SDN Sumurjalak Plumpang Tuban. Sedangkan data sekunder diperoleh melalui dokumendokumen tertulis serta foto maupun video. Teknik pengumpulan data melalui observasi, wawancara, dan dokumentasi. Analisis data dalam penelitian ini menggunakan model interaktif yaitu proses reduksi data, proses penyajian data, dan penarikan kesimpulan.

\section{Hasil}

Hasil penelitian tentang metode pembelajaran kontekstual IPA di SDN Sumurjalak 2 Plumpang Tuban yang dilakukan dengan wawancara dan observasi terhadap beberapa responden, yaitu kepala sekolah dan guru dan peserta didik SDN Sumurjalak 2 Plumpang Tuban. Model pembelajaran kontekstual IPA di SDN Sumurjalak 2 Plumpang Tuban dalam pembelajaran IPA meliputi: (1) Menjalin hubungan-hubungan yang bermakna dalam proses pembelajaran IPA, (2) Mengerjakan pekerjaan-pekerjaan yang berarti dalam proses pembelajaran IPA, (3) Peserta didik menemukan sendiri dalam proses pembelajaran IPA, (4) Mengadakan kolaborasi dalam proses pembelajaran IPA, (5) Berpikir kritis dan kreatif dalam proses pembelajaran IPA, (6) Penggunaan media pembelajaran dalam proses pembelajaran IPA, (7) Refleksi dalam proses pembelajaran IPA, (7) Menggunakan asesmen autentik dalam proses pembelajaran IPA. 
Adapun penjelasannya adalah sebagai berikut: Hasil dari penelitian di SDN Sumurjalak 2 Plumpang tuban mengenai Outdoor Learning meliputi: (1) Lingkungan yang ada di dalam lingkup sekolah yaitu: kebun sekolah, rumah toga, area outbound, lapangan, dan rumah joglo. (2) Lingkungan di luar sekolah yaitu tracking dan outing. Tempat-tempat tracking yang sering di kunjungi adalah sungai, pantai, penangkaran mangrove, sawah, perkebunan warga, dan perumahan. Sedangkan tempat-tempat outing yang sering di kunjungi peserta didik SDN Sumurjalak 2 Plumpang Tuban adalah museum sejarah, pengolahan industri tempe, industri tahu, kebun binatang, pabrik roti, dan museum tubuh.

Pendekatan Outdoor Learning di SDN Sumurjalak 2 Plumpang Tuban merupakan salah satu kegiatan sekolah yang dapat meningkatkan kapasitas belajar peserta didik dalam proses pembelajaran. Peserta didik dapat belajar lebih memahami materi melalui objek-objek yang dipelajari dan dihadapi dari pada jika belajar di dalam kelas (Indoor) saja yang memiliki banyak keterbatasan. Kegiatan belajar luar kelas (Outdoor Learning) dapat membantu peserta didik untuk mengaplikasikan pengetahuan yang telah meraka miliki. Selain itu, pembelajaran di luar kelas (Outdoor Learning) dapat menjadi perantara antara teori yang ada di dalam buku dan kemudian di aplikasikan secara kenyataan yang ada di lapangan. Kualitas pembelajaran dalam situasi yang nyata memberikan peningkatan kapasitas capaian pembelajaran melalui objek yang dipelajari. Kegiatan luar kelas (Outdoor Learning) dapat membangun ketrampilan sosial dimana peserta didik belajar secara berkelompok, serta membangun keterampilan personal yang lebih baik. Pembelajaran dengan menggunakan pendekatan Outdoor Learning dapat dilakukan kapanpun sesuai dengan rencana program yang dibuat oleh guru dan di koordinasikan bersama wali murid. Hasil dari penelitian SDN Sumurjalak 2 Plumpang Tuban merupakan SD yang telah menerapkan model pembelajaran kontekstual IPA melalui pendekatan Outdoor Learning.

Model pembelajaran kontekstual merupakan model pembelajaran yang menekankan proses keterlibatan siswa secara oenuh untuk dapat menemukan materi yang dipelajari dan menghubungkan dengan keadaan nyata secara langsung yang dapat mendorong peserta didik untuk menerapkan dalam kehidupan sehari-hari. Sedangakan pendekatan Outdoor Learning merupakan suatu kegiatan di luar kelas yang dapat menjadikan pembelajaran di luar kelas menarik dan menyenangkan. Kegiatan Outdoor Learning bisa dilakukan dimanapun dengan menekankan pada proses belajar berdasarkan fakta nyata, yang materi pembelajaran dabn 
pengalaman peserta didik secara langsung dengan harapan peserta didik dapat lebih membangun makna dan kesan dalam memori atau dalam ingatanya.

Adapun hasil dari model pembelajaran kontekstual IPA melalui Outdoor Learning di SDN Sumurjalak 2 Plumpang Tuban adalah:

a. Pembelajaran Kontekstual IPA Melalui Lingkungan yang ada di sekitar Sekolah Pembelajaran kontekstual IPA dengan menggunakan pendekatan Outdoor Learning dapat merangsang otak untuk menyusun pola-pola yang mewujudkan makna. Melalui pemaduan materi yang dipelajari dengan pengalaman keseharian peserta didik akan menghasilkan dasardasar pengetahuan yang mendalam, peserta didik akan mampu menggunakan pengetahuannya untuk menyelesaikan masalah-masalah baru dan belum pernah dihadapinya dengan peningkatan pengalaman dan pengetahuannya. Peserta didik diharapkan dapat membangun pengetahuannya yang akan diterapkan dalam kehidupan sehari-hari dengan memadukan materi pelajaran yang telah diterimanya di sekolah serta menghubungkan materi tersebut dengan materi yang telah di milikinya. Belajar bermakna terjadi melalui refleksi, pemecahan konflik, pengambilan keputusan, dan dalam prosesnya tingkat pemikiran selalu diperbaharui sehingga menjadi semakin lengkap. Pembelajaran menjadi bermakna jika pelajaran yang dipelajari berharga bagi peserta didik, sehingga tugas peserta didik adalah menangkap dan memahami hubungan dalam keseluruhannya.

b. Pembelajaran Kontekstual IPA Melalui Lingkungan di Luar Sekolah

SDN Sumurjalak 2 Plumpang Tuban mengajak peserta didiknya untuk selalu berpikir kritis dan guru memanfaatkan model pembelajaran kontekstual dengan menggunakan pendekatan Outdoor Learning dalam pembelajaran IPA. Pendekatan kontekstual mengutamakan aktivitas siswa untuk emmbangun pengetahuannya secara mandiri dengan terlibat secara aktif dan membutuhkan pemikiran secara kritis peserta didik. Keterampilan berpikir kritis bukan merupakan suatu keterampilan yang dapat berkembang dengan sendirinya seiring dengan perkembangan fisik manusia. Keterampilan ini harus dilatih melalui pemberian stimulus yang menuntut seseorang untuk berpikir kritis. Sekolah sebagai suatu institusi penyelenggara pendidikan memiliki tanggung jawab untuk membantu peserta didiknya mengembangkan keterampilan berpikir kritis. Keterampilan berpikir kritis merupakan suatu proses intelektual tentang konseptualisasi, penerapan, analisis, sintesis, dan evaluasi secara aktif dan mahir 
terhadap informasi yang diperoleh dari observasi, pengalaman, refleksi, pemikiran, atau komunikasi sebagai pedoman untuk meyakini dan bertindak.

\section{Kesimpulan}

Berdasarkan hasil informasi, data, temuan dan pembahasan, maka hasil penelitian tentang Pembelajaran Kontekstual IPA Melalui Outdoor Learning di SDN Sumurjalak 2 Plumpang Tuban dapat disimpulkan bahwa: (1) pembelajaran IPA dengan menggunakan model pembelajaran kontekstual dapat meningkatkan pemahaman konsep peserta didik. Dalam pembelajaran menggunakan kontekstual guru mampu mengondisikan peserta didik dengan menekankan kepada proses keterlibatan peserta didik secara penuh untuk dapat mengkostruksikan sendiri materi yang dipelajari dan menghubungkan dengan situasi kehidupan nyata sehingga mendorong peserta didik untuk dapat menerapkannya dalam kehidupan mereka. (2) pendekatan Outdoor Learning merupakan salah satu alternatif pembelajaran IPA yang cocok dengan melakukan petualangan dan pengamatan secara langsung di lingkungan nyata di sekitar dengan mengkaitkan sains, lingkungan, teknologi dan masyarakat. (3) model pembelajaran kontekstual dalam pembelajaran IPA mampu menyajikan pembelajaran IPA yang konstruktif serta memberikan hasil belajar yang lebih bermakna bagi peserta didik. Peserta didik dapat menemukan menyusun sendiri pengetahuannya sehingga menjadi lebih bermakna dan tidak mudah dilupakan, peserta didik mudah memahami materi, peserta didik mengerjakan tugas-tugas yang berati, serta peserta didik lebih kritis dan kreatif dalam tanya jawab dalam pembelajaran IPA.

\section{Daftar Referensi}

Agustin, Nurhaningtyas \& Munthofi'ah. (2019). PENERAPAN MODEL BELAJAR INKUIRI UNTUK MENINGKATKAN PRESTASI BELAJAR IPA DALAM MATERI POKOK DAUR HIDUP PADA SISWA KELAS V MI SUNAN KALIJOGO. PREMIERE : Journal of Islamic Elementary Education, 1(1), 87-102.

Suprijono, Agus. 2009. Cooperative Learning Teori dan Aplikasi Paikem. Yogyakarta: Pustaka Belajar.

Suryanti, dkk. 2008. Model-Model Pembelajaran Inovatif. Surabaya: Unesa University Press 
Sanjaya, Wina. 2008. Strategi Pembelajaran Berorientasi Standar Proses Pendidikan. Jakarta: Kencana.

Sudjana, Nana dan Ibrahim. 2007. Penelitian dan Penilaian Pendidikan. Bandung: Sinar Baru Algensindo.

Trianto. 2009. Mendesain Model Pembelajaran Inovatif-Progresif, Jakarta: Kencana.

Widi Wisudawati, Asih dan Eka Sulistyowati. 2014. Metodologi Pembelajaran IPA, Jakarta: Bumi Aksara. 